\title{
Directions in Dental Anthropological Research in Hungary, with Historical Retrospect
}

FERENC KÓSA

Department of Forensic Medicine, Albert Szent-Györgyi Medical University, H-6724 Szeged, Kossuth Lajos sugárút 40, Hungary

\section{BRIEF HISTORY OF ANTHROPOLOGY}

Anthropology as a science began to develop rapidly in Hungary during the middle and latter part of the 19th century. The Eighth World Congress of Prehistory and Anthropology, held in Budapest in 1876, stimulated this development. The congress aroused the interest of many individuals working in different fields of anthropology, most notably S. Scheiber, the anthropologist (Scheiber, 1873); F. Römer, the archaeologist (Eiben, 1988); and J. Lenhossék, the anatomist (Lenhossék, 1875).

The intellectual endeavors of scientists, together with changes in international relations, resulted in the establishment of the Department of Anthropology at Péter Pázmany University of Natural Sciences in Budapest in 1881. Aurél Török (1842-1912) was the first university professor in the department. Previously, he had worked in the Department of Forensic Medicine, Pathology, Anatomy, and Physiology of the Medical Academy in Kolozsvár. Török had obtained much of his knowledge during trips abroad (Paris), where he studied human anatomy and biology. Thus, his published works deal with paleopathology and the study of the human skull (Török, 1882, 1890, 1898, and 1899).

\section{EARLY ANTHROPOLOGISTS}

Between World Wars I and II, M. Lenhossék (1836-1937) investigated hominid evolution and paleoanthropology (Lenhossék, 1915, 1917, 1917a, 1918, 1919, 1920, 1921, and 1922). After 1940, L. Bartucz (1885-1966), who had been a professor at the Institute of Anthropology in Budapest since 1931, directed the Institute of Anthropology in Szeged. To improve the teaching of anthropology at the university, Bartucz distributed lecture notes about topics of anthropology and human evolution. Bartucz' (1914, 1935, and 1966) publications stand out in the field of paleoanthropology, and the data in his 1966 monograph on prehistoric trepanation are especially noteworthy.

M. Malán (1900-1968) was another important anthropologist of this century. He organized a modern Institute of Anthropology and established anthropological education and research at the University in Kolozsvár. (Kolozsvár in Transylvania had been reannexed to Hungary). Later, Malán directed the Institute of Anthropology in Budapest, after the retirement of Bartucz.

J. Nemeskéri (1914-1990), a student of Bartucz, was lecturer and non-staff teacher at the University in Debrecen. He was also director of the Demographic Research Institute of the Central Statistical Office. In 1959, Nemeskerri contributed to the success of the symposium, "Anthropological Questions of the Carpathian Basin", held in Budapest. A similar symposium, "Evolutionary Trends in Fossil Hominids" was held in 1967 in Budapest and Eger. Seven years later in 1974, two international series of lectures were given: "The Question of Age and Sex Determination" in Budapest and "Paleodemography" in Sárospatak. His major publications are Nemeskéri (1943, 1947; Nemeskéri and Harsányi, 1968; Nemeskéri and Dezsö, 1969; and Nemeskéri, Harsányi, and Acsadi, 1960). 


\section{UNIVERSITIES AND MUSEUMS}

The scientific activities of anthropologists in the departments of anthropology in the three universities and the larger museums were noteworthy. In 1975, D.G. Eiben took over as director of the Institute of Anthropology in Budapest. On the basis of his position and activities, he is considered the directing personality of anthropology in Hungary. His research has been directed mainly toward physical anthropology, biology, and human ecology (Eiben, 1982, 1988).

Meanwhile, P. Lipták succeeded Bartucz as director of the Department of Anthropology of Attila Jozsef University of Science (JATE) in Szeged. His interests have focused on anthropological taxonomy and paleoanthropology (Lipták, 1967, 1969, 1976). In 1969 Lipták published, Anthropology and Human Evolution, the first anthropology textbook printed in Hungary. Another of his books, Avars and Ancient Hungarians (Lipták, 1983), deals with the origin of the Hungarian People on the basis of osteological discoveries and evidence from linguistics, archaeology, ethnography, and other prehistoric information.

Gy. Farkas has directed the Department of Anthropology in Szeged since 1980. His scientific work is aimed at investigation of prehistoric skeletal material in the southwestern part of the Hungarian plain in order to obtain data on growth, maturation, and acceleration rate of juveniles (Farkas, 1969, 1972; Farkas and Marcsik, 1975, 1979).

I. Lengyel (1970-1992) gave special lectures on results of paleo-serological studies, which he carried out at the Department of Anthropology in Szeged and later in Budapest. These results have been described in a monograph Paleoserology, Blood Typing with the Fluorescent Antibody Method (Lengyel, 1975).

\section{DENTAL ANTHROPOLOGY}

Dental anthropology is not completely isolated from the science of anthropology, yet to some extent it is an independent unit. In Hungary dental anthropology encompasses three specialties: anthropology, stomatology (dentistry), and forensic anthropology (forensic osteology and stomata-odontology). Nearly all researchers dealing with anthropology are interested in dental anthropology. Evidence can be found in Kocsis' (1989) literature review and bibliography, which contains 172 citations of publications about maxillary and mandibular morphology, dental morphology, mandibular pathology, dental morphological feature, dental caries, tooth wear, periodontal lesions and periapical changes, illness and dental development, and pseudopathological deformations from data from Hungarian excavations.

\section{Research Cited in Kocsis (1989)}

Publications on maxillary and mandibular morphology discussed in Kocsis' review (1989) are works by Apor (1943), Balogh and Csiba (1966), L.Bottyán (1968, 1970a, 1970b, 1971, 1973, 1974a, 1974b, 1975), Dobrovits (1966), Dobrovits and Kemény (1971), Farkas and Marcsik (1979), Finnegan and Marcsik (1979, 1980), Földes et al., (1981), Kollár (1948), Könegyi and Marcsik (1976), Lang (1955), Lenhossék (1915, 1917a, 1917b, 1918, 1919, 1920, 1921, 1922), Nitsche and Vályi (1958), Prágai (1982), Prágai and Fazekas (1982, 1983), Regöly-Mërei and Nemeskëri (1958a, 1958b), Rudas (1989a, 1989b), Simon and Kömives (1937), Somogyi (1953), Szabö and Doby (1972), Szokolóczy-Sillaba (1937, 1939, 1953), Tamás (1986), and Török $(1882,1890,1898,1899)$.

Publications on pathology are those by Berndorfer (1962), Jojárt (1988), Kemenes (1970), Marcsik (1976, 1983), Marcsik and Kocsis (1985), Nemeskéri (1943, 1947), Nemeskéri and Harsányi (1968, 1969), Regöly-Mérei and Nemeskéri (1958a, 1958b), Somogyi (1953), and Schranz (1953). Works on dental morphological structures are those by Alaodiatoris (1937), Bartucz $(1914,1935,1966)$, Hillebrand (1908a, 1908b, 1909), Iszlay (1881a, 1881b), Lenhossék (1985, 1915, 1917a, 1917b, 1918, 1919, 1920, 1921, 1922), Malán (1944, 1955, 1961), Molnár and Huszár (1953), Salamon (1923, 1938, 1940a, 1940b, 1941, 1942), Schranz (1953, 1956, 1962, 1964, 1967, 1988), Schranz and Huszár (1954, 1955, 1958, 1962), Szabó $(1934,1935)$, Thoma $(1963,1966,1967)$, and Török $(1882,1890,1898,1989)$. Works on dental caries have been published by Brabant (1962, 1971), Brabant and Nemeskéri (1963), Bruszt (1950a, $1950 \mathrm{~b}$. 1950c, 1952, 1953a, 1953b, 1954, 1958, 1963, 1966, 1975), Bruszt and Könegyi (1963), Endrësz.(1986), Éry (1971, 1981, 1982), Hillebrand (1908a), Huszár (1945, 1951, 1961, 1963, 1965, 1966, 1967, 1968, 1972, 1974a, 1974b, 1976), Huszár and Schranz (1952), Kiszely (1966), Kollár (1948), Lenhossék (1919), Schranz (1956, 1962, 1964, 1964, 1988), Schranz and Huszár (1954, 1955, 1958, 1962), Szikáry and Huszár (1933), Tóth (1966a, 1966b, 1966c, 1967a, 1967b, 1967c, 1967d, 1968, 1970a, 1970b), and Toth and Sonkodi (1972). 
Works on the cultural history of dental wear are those by Huszár and Schranz (1954), Mathé and Molnár (1940), Molnár (1939), and Schranz and Huszár (1954, 1955). Works on periodontal lesions and periapical changes have been written by Pap (1986) and Szarvas (1981). Publications on disease and developmental anomalies are those by Arkövy (1904a, 1904b), Hajós (1989), Kocsis (1989), Kocsis and Marcsik (1979, 1980, 1981, 1982, 1983a, 1983b, 1987, 1989, 1991), Kocsis and Mari (1988), Kocsis and Trogmyer (1986), Kocsis, Marcsik, and Mann (1992), and Salamon (1923, 1938, 1940a, 1940b, 1941, 1942).

\section{Work by Dentists}

Dentists (stomatologists), who are experts at dental anthropology, have worked at four Hungarian medical universities and three dental clinics. D. Schranz, Gy Huszár, and G. Szabó have worked at the Dental Clinic of Semmelweis Medical University. Previously, P. Adler and A. Szentpéteri worked at the Stomatological Clinic of the Medical University in Debrecen. D. Hattyasy, S. Ponyi, K. Tóth, and G. Prági have worked at the Dental Clinic of Albert Szent-Györgi Medical University in Szeged. Presently, A. Mari, A. Fazekas, and G.S. Kocsis work there. Publications include those by Schranz (1953, 1956, 1957, 1962, 1988); Schranz and Huszár (1954, 1955, 1958, 1962), Pónyi and Nyilasi (1971) Pónyi and Szabó (1989), Toth $(19661,1966 b, 1966 \mathrm{c}, 1967 \mathrm{a}, 1967 \mathrm{~b}, 1967 \mathrm{c}, 1967 \mathrm{~d}, 1968,1970 \mathrm{a}, 1970 \mathrm{~b}, 1980 / 81)$, Toth and Sonkodi (1972), Kocsis (1988, 1989), Kocsis and Marcsik (1979, 1980, 1981, 1982, 1983a, 1983b, 1987, 1989, 1991), Kocsis and Mari (1988), Kocsis and Trogmyer (1986), and Kocsis, Marcsik, and Mann (1992).

The work of these individuals focuses on archaeological dental discoveries in addition to modern dental medicine. Schranz has actively pursued projects of identification of individuals through teeth (Schranz, 1953), prehistoric investigation of paradentosis (Schranz, 1962), evaluation of dental wear by dental and culture-historical use of fossil teeth, and dental disease and the appearance of caries in prehistoric peoples (Schranz, 1856, 1964, 1988; Schranz and Huszár, 1954, 1955, 1958, 1962).

K. Toth has worked on similar projects. His observations on archaeological skeletal materials led to his study of connections between civilization, dental caries, and origins and results of dental pathology. He has also investigated the frequency of caries during the seventh to the thirteenth centuries AD (T6th, 1966a, 1966b, 1966c, 1967a, 1967b, 1967c, 1967d, 1968, 1970a, 1970b, 1980/81; Toth and Sonkodi, 1972).

G.S. Kocsis was a student of Toth at the Medical University in Szeged. He continues to study archaeological skeletal materials. (Kocsis, 1988; Kocsis and Marcsik, 1979, 1980, 1981, 1982, 1983a, 1983b, 1987, 1989; Kocsis and Mari, 1988; Kocsis and Trogmyer, 1986; Kocsis, Marcsik, and Mann, 1992; Marcsik, 1989; Marcsik and Kocsis, 1984, 1985 1986; and Marcsik, Kósa, and Kurucz, 1984).

In addition to these publications, some important studies in clinical dentistry must be mentioned. For example Vajdovich and Dinnyés (1989) have enhanced our knowledge of anatomical and typographic relationships of the mandible through a study which corrected earlier information about the course of the mandibular canal. Pónyi and Szabó (1956), through a study of 38 reference points on 528 historical mandibles, established reference points for the placement of mandibular protheses. In several papers, Prágai and Fazekas (Prágai, 1982; Prágai and Fazekas, 1982, 1983) have reported the results of their investigations of the height of the mandibular spine in the region of molar teeth. Finally, Toth's (1980/81) report on the frequency of "buck teeth" in Hungary is interesting from an anthropological point of view.

\section{Forensic Dental Anthropology}

Forensic medical sections of Hungarian dental anthropology have dealt with important subjects. For example, L. Harsányi (1924-1992) director of the Forensic Medical Institute of Pécs, used scanning electron microscopy to measure morphological changes in cremated teeth (Harsányi, 1977; Harsányi and Nemeskéri, 1962 , 1964). By exposing teeth to temperatures ranging from $200^{\circ}$ to $1200^{\circ} \mathrm{C}$, he could estimate the amount of heat applied through observation of morphological changes in the dentine. As a result, he concluded that teeth from a cremation burial cemetery in Issendorf, Germany, had been exposed to temperatures between $200^{\circ}$ and $900^{\circ} \mathrm{C}$.

My own work has dealt with forensic osteology for nearly 30 years. Examples of publications are Kósa (1978, 1984, 1989, 1990a, 1990b); Kósa, Szendrényi, and Tóth (1978); Kósa, Ferenczi, and Baláspiri (1985); Kósa and Antal (1988); Kósa, Farcas, and Wittman (1989); and Kósa, Antal, and Farkas (1990).

My first paper, published in 1966, dealt with fetal bones. "Estimation of fetal body length and age on the basis of bone measurements" was the subject of my Candidate's dissertation in 1969, and "Individual and Chronological Age of Human Bones" was the topic of my academic Doctor of Science dissertation in 1990. 
My investigation was aimed at the estimation of age and its limits through research carried out with atom absorption spectrophotometry, automatic amino acid analysis, polarization optics, scanning electron microscopy, and electron probe analysis of osteological and dental samples.

I have published 38 papers and delivered approximately 70 scientific lectures in the field of forensic osteology. One of my best known works is the book, Forensic Fetal Osteology (Fazekas and Kósa, 1978), which summarizes all the information useful for forensic anthropology, age estimation, and paleoanthropology. Additional publications in books are Clement and Kósa (1989), Kósa (1978, 1989), and Marcsik, Kósa, and Kocsis (1992).

Part of my scientific odontological work has been done with A. Marcsik, first assistant at the Department of Anthropology of Joseph Attila University of Science in Szeged. Another portion is carried out with my co-workers at the Institute and at the Medical University.

My forensic odontological investigations on the estimation of individual age can be summarized as follows: age dependent translucency phenomenon observed on the roots of teeth can determine the age of an individual, in both recent and historical osteological discoveries (Kósa, Szendrényi, and Tóth, 1983). According to our findings, secondary dentine formation generates changes in dimension that show a definite correlation with age (Kósa and Antal, 1988).

Dentine tubules for age estimation have been studied by scanning electron microscope. Results show a significant correlation $(\mathrm{P}<0.01)$ between metrics and structure of dentine tubules and age. Therefore, the mean value of dentine tubules provides a good means for estimating individual age (Kósa, 1984). The electron microscope was also used for studying finer dentine structures associated with age. On the teeth of older individuals (over 50) a granular loose structure appears instead of the homogeneous structure of intertubular basic dentine substance. A definite hypermineralization can be seen around the few diminished dentine tubules (Kósa, 1984).

Using atom absorption spectrophotometry, we studied the inorganic content of human teeth and assayed calcium, sodium, potassium, magnesium, iron, zinc, copper, lead, and lithium (Földes et al., 1981). Our results show that the concentration of inorganic elements in teeth is significantly higher than those in bones $(\mathrm{P}<0.05)$.

Using electron probe microanalysis, we established that the calcium-potassium weight ratio is higher on the surface of the hypermineralized zone around the dentine tubules than it is in the basic substance between the tubules. Thus, the electron probe microanalysis method offers an excellent means for identifying the age of an individual in dental samples (Kósa, Antal, and Farkas, 1990).

\section{Historical Anthropological Work Team}

At the present time, the most intensive dental anthropological research is done in Szeged. The Historical Anthropological Work Team, led by A. Marcsik, has been studying skeletal materials from archaeological excavations. Marcsik defended her Candidate's dissertation in paleoanthropology and paleopathology on "Paleopathology of the Avar Period in the Area between the Danube and Tisza" (Marcsik, 1983).

Another well-known member of the team is G.S. Kocsis, who this year wrote his Candidate's thesis entitled "Developmental Anomalies of the Teeth". Kocsis has studied Avar skeletal materials for a number of years, and has co-authored papers on extra-dental paracoronal formations of tooth enamel (Kocsis and Marcsik, 1980), abnormal dental enamel (Kocsis and Marcsik, 1981), and tooth position disorders on Avar teeth (Kocsis and Marcsik, 1982).

I have also worked with the team to solve specific research problems. Professor Michael Finnegan from Kansas State University has worked with us on several projects. Among these are studies of the relationships of Avar Period skeletal materials in Hungary (Finnegan and Marcsik, 1978) and Stafne defect in archaeological and recent samples (Finnegan and Marcsik $(1980,1981)$.

Our work has also dealt with the etiology of dental enamel disorders, invagination of the coronary end (Kocsis and Marcsik, 1987), frequency of double-rooted dens caninuses, and frequency of dental developmental disorders (Marcsik and Baglyas, 1987). We have also described and analyzed paleoanthropological discoveries (Marcsik, 1976, 1983, 1989; Marcsik, Kocsis, and Kurucz, 1984; Marcsik and Kocsis, 1984, 1985, 1986, 1992; Marcsik and Baglyas, 1987; and Maresik, Kósa, and Kocsis, 1992).

Members of the Historical Anthropological Work team are also studying the prevalence of a developmental disorder of the head of the mandibular joint (condyilus bifidus) and disorders of Avar period skulls (Szentpëtery, Kocsis, and Marcsik, 1990). The work team has also published information on the 
anomaly of "adventitious roots" of maxillary central incisors (Kocsis and Marcsik, 1989), morphological properties, and simultaneous occurrence of porotic hyperostosis, dental enamel hypoplasia, and Harris lines in a collection of eighth to tenth century skeletons (Marcsik, 1989). The teeth in this collection have also been studied for dens invaginate and palatolingualis grave as a secondary pathosis. These these data have then been compared with teeth from the Neolithic Era to the Middle Ages (Kocsis and Marcsik, 1991). The same authors have also published a paper on the phenomenon of an unidentified "cavity" in bones" on the surface of the posterior part of the mandible (Kocsis, Marcsik, and Mann, 1992).

Recently, the team was invited to write an article on developmental enamel disorders and the occurrence of enamel hypoplasia in prehistoric and historic Hungarians (Marcsik and Kocsis, 1992). We have also written an article based on our paper at the Eighth International Congress on Dental Morphology. The subject is age determination through the transparency of teeth based on a study of historical archaeological materials (Marcsik, Kósa, and Kocsis, 1992).

At the present time, A. Marcsik, G.S. Kocsis, and F. Kósa are the only active Hungarian specialists who are members of the Dental Anthropology Association.

\section{Author's Note}

My task, on behalf of the editorial board of the Dental Anthropology Newsletter has been to describe the recent scientific tendencies of dental anthropology in Hungary and to introduce prominent representations of the sciences and the latest results in the frame of a short historical review. I hope that anyone that I have omitted will not be offended, as the limits available permitted mention of the most well known scientists contributing to the growth and development of anthropology in Hungary. In addition, Hungarian-language references have been translated into English.

\section{LITERATURE CITED}

Alaodiatoris I (1937) Adatok as Arpádkori Alföldi Magyarság Anthropologiájához [Data on the Anthropology of Hungarian Plainsmen]. Budapest: Dissertation.

Andrik P (1965) Paleostomotologóiai kutatások eredményei és azok jelentösége. [Results and importance of paleostomatological investigations]. Fogorv. Szle. 58:357-363.

Apor L (1943) Az állkapocsszélesség jelentösége [Importance of the breadth of the mandible]. Ttud. Közl. 75:217-218.

Arkövy J (1904a) Néhány eddig ismeretlen reductiós jelenségröl a fogakon, statisztikailag megvizsgálva [Some unidentified reduction phenomena on teeth. Statistical evaluations]. MTA Mat. Ttud. Ért. 22:21-28.

Arkövy J (1904b) Die Bedeutung des Diverticulum Tomes-Zsigmondy, des Cingulum and den oberen lateralen Scheidezähnen und des Foramen coecum molarium (Milleri) in phylogenetischer Beziehung. Österr. Ung. Viertelj. Zahnheilk. $20: 13-34$.

Balough K, and Csiba A (1966) Az "area perilingualiris" tájbonstani variációi [Variations of the regional anatomy of "area perilingualiris"]. Fogorv. Szle. 59:289-293.

Bartucz L (1914) A weimari ösemebr állkapcsa [Mandible of the Weimar prehistoric man]. Ttud. Közl. 46:154-156.

Bartucz L (1935) II. Rákóczi Ferenc hamvai [The mortal remains of Ferenc Rákóczi II]. Ttud. Közl. 67:214-222.

Bartucz L (1966) A praehistorikus trepanáció és orvostörténeti vonatkozásu sirleletek [Prehistoric trepanation and burial discoveries related to the history of medicine]. Paleopathologia III. Medicina. Budapest.

Berndorfer A (1962) A 500 year old skull with cleft lip. Br. J. Plast. Surg. 15:123.

Bottyán O (1968) An analysis of palatal measuring methods. Ann. Hist. Nat. Mus. Nat. Hung. 60:297-306.

Bottyán O (1970a) Changes in the palate owing to age. In I Törö, E Szabady, J Nemeskéri, and OG Eiben (eds.): Advances on Biology of Human Populations. Budapest: Akadémai Kiadó, pp. 437-477.

Bottyán O (1970b) Variations of the palatum with respect to sexual dimorphism. I. Ann. Hist. Nat. Mus. Nat. Hung. 62:393-404.

Bottyán O (1971) Variations of the palatum with respect to sexual dimorphism. II. Ann. Hist. Nat. Mus. Nat. Hung. 63:409-420.

Bottyán O (1973) The correlation of mandibular and cranial capacity. Ann. Hist. Nat. Mus. Nat. Hung. 65:317-322.

Bottyán O (1974a) Sexual dimorphism of the human mandible. Ann. Hist. Nat. Mus. Nat. Hung. 66:403-411.

Bottyán O (1974b) A csontos szájpad (Palatum) vizsgálatának eredményei [Results of the investigation of the bony palate]. Anthrop. Közl. 18:29-34.

Bottyán O (1975) Lebensalterwandlungen der Mandibel. Ann. Hist. Nat. Mus. Nat. Hung. 67:333-342.

Brabant H (1962) Az európai ember fogazatának alakulása az utóbbi 5000 évben [Development of the teeth of European man in the last 5,000 years] Fogorv. Szle. 55:439-442.

Brabant H (1971) Étude odontologique des squelettes du cimetiére scythe de Szabadszállás-Józan, Hongrie. Bull. Soc. Roy. Belge Anthrop. Prehist. 82:25-52.

Brabant H, and Nemeskéri J (1963) Mözs községben felfedezett kunkori koponyák anthropologiai és stomatologiai tanulmányozása [Anthropological and stomatological studies of skulls of Hun Age discovered in a village named Mözs]. Bull. Group. Rech. Sci. Stomatol. 6:317-338.

Bruszt P (1950a) Untersuchungen über das Vorkommen von Zahnkaries an Schädeln aus dem X-XII. Jahrhundert. österr. Zschr. Stomatol. 11:483-490. 


\section{DENTAL ANTHROPOLOGY IN HUNGARY}

Bruszt P (1950b) A "dens in dente" keletkezéséröl [On the formation of "Dens in Dente"]. Fogorv. Szle. 43:305-311.

Bruszt P (1950c) Über die Entstehung des "Dens in Dente" Schweiz. Monatschr. Zahneheilk. 60:534-542.

Bruszt P (1952) 1128a VII-XIII. századból származó koronya viszgálata a fogszuvasodás szempontjából [Investigation of a skull originating from VII-XIII century concerning dental caries]. Fogorv. Szle. 45:72-77, 105-112.

Bruszt P (1953a) Über die Verdoppelung der Milcheckzähne. Dtsch. Stomatol. 3:47-49

Bruszt P (1953b) Ketgyökerü felsö szemfog [Double-rooted upper canine]. Fogorv. Szle. 46:146-147.

Bruszt P (1954) Ein oberer bleibender Eckzahn mit zwei Wurzeln. Dtsch. Stomatol. 4:78-79.

Bruszt P (1958) A Györött feltárt késö római kori csontvázleletek vizasgálata fogszuvasodás tekintetében [Examination of skeletal discoveries with regard to dental caries. Dated from the Roman period in Györ]. Anthrop. Közl. 1:49-50.

Bruszt P (1963) Über seltene Form-, Zahlen- und Lageanomalien der Eckzännen. Stoma. 16:172-180,208-213.

Bruszt P (1966) Examen des ossements des morts tombée pendant le siége d Eger (Hongrie) en 1552 et conservés á 1 ossaire de la fortresse. Origine de ces ossements et caractéres odontoloigues. Bull. Group. Int. Rech. Sci. Stomatol. Odontol. 9:171-178.

Bruszt P (1975) Több évtizedes tudományos munkásságának tézisei [Theses of his scientific activity for several decades]. Baja.

Bruszt P, and Könegyi M (1963) Az egri vár "csontfülkéjében" örzött, az 1552-es ostrom alat elesettek csontmaradványainak eredete és fogászati vizsgálata [Origin and dental investigation of the rest of the bones of the heroes fallen at the siege of the fortress in Eger in 1552. Finds were protected in the "cabin for bones"]. Comm. Bibl. Hist. Med. Hung. 28:45-54.

Clement JG, and Kósa F (1989) The fetal skeleton. In DH Clark (ed.): Practical Forensic Odontology. Oxford: WrightButterworth, pp. 43-52.

Dobrovits T (1966) A retromolaris tájék csonttani adottságai es topográfiai helyzetének meghatározása [Determination of the natural osteological and topographical position of the retromolar region using anthropological measure points]. A 9. Árkövy Vándorgyülés elöadásainak rövid összefoglalása. Szeged.

Dobrovits T, and Kemény I (1971) Mérések a retromolaris tájék csontfelszinén [Measurements on the bone surface in the retromolar region]. Fogorv. Szle. 64:205-212.

Eiben OG (1982) (ed.) Growth and Development; Physique Symp. Biol. Hung. Vol. 20. Budapest: Akadémiai Kiadó.

Eiben OG (1988) History of Human Biology in Hungary. International Association of Human Biologists. Occasional Papers, Vol. 2, No. 4.

Endrész F (1986) Paradontológiai csontelváltozások vizsgálata Árpád-kori koponyákon [Investigation of paraodontological bone alterations on skull from Árpád Age]. Skakdolg. Szeged: Szote.

Éry K (1971) The anthropological examination of a tenth century population at Tengelic, Hungary. Anthrop. Hung. 10:49-89.

Éry K (1981) Anthropolgische Analyse der Population von Tokod aus dem 5. Jahrhundert. In A Mócsy (ed.): Die Spätrömische Festung und das Gräberfeld von Tokod. Budapest: Akadémiai Kiadó, pp. 223-263.

Éry K (1982) Balkáni eredetü törökkori népesség csontmaradványai Dombóvár határából [The rest of the bones of populations of Turkish Age which originated from the Balkans and discovered in the confines on Domobár]. Szekszárdi Béri Balogh Adám Muzeum Évk. 1979-1980 10-11:225-298.

Farkas Gy (1969) Untersuchungsergebnisse an Knaben un Mädchen aus Szeged (Südungarn) unter besonderer Berücksichtigung der Reifungsmerkmale. Wiss. Z. Humbolt Univ. Berlin, Math. Nat. Rer. 18:931-940.

Farkas Gy (1972) (ed.) Practical Manual of Anthropology. Paleoanthropological Methods, 1. Methods on Moving Populations, 2. Szeged: József Attila University.

Farkas Gy, and Marcsik A (1975) Anatomical variations and paleopathological observations in prehistoric series. Acta Biol. Szeged 21:147-163.

Farkas Gy, and Marcsik A (1979) Paleopathologische Fälle in der awarenzeitlichen Serie von Backa-Topola, SFR Jugoslawien. EAZ 20:15-33.

Fazekas IGy, and Kósa F (1978) Forensic Fetal Osteology. Budapest: Akadémiai Kiadó.

Finnegan M, and Marcsik A (1979) A non-metric examination of the relationships between osteological remains from Hungary representing populations of Avar period. Acta Biol. Szeged 25:97-118.

Finnegan M, and Marcsik A (1980) Anomaly or pathology: The Stafne-defect as seen in archaeological material and modern clinical practice. J. Hum. Evol. 9:19-31.

Finnegan M, and Marcsik A (1981) The description and evidence of the Stafne idiopathic bone defect in six Avar populations. Acta Biol. Szeged 27:315-221.

Folders V, Kósa F, Virágos, Kis E, and Rendegei B (1981) Untersuching des Gehaltes der menschlichen Zähne an anorganischer Sustanz mittels Atomabsorptions-spektrophtometrischer Methode. Beiträge zur gerichtl. Medizin. Wissenschftl. Schriften der Humboldt Univ. zu Berlin S. 253-259.

Hajós I (1989) Alsó kétgyökerü szemfogak gyökereinek morfológiája [Morphology of the roots of the double-rooted lower canine]. Szakdolgozat. Szeged: Szote.

Harsányi L (1977) Scanning electron microscope examinations of teeth finds from cremation burials. Anthrop. Közl. 21:3-14.

Harsányi L, and Nemeskéri J (1962) Investigations of age of change in the compact substance of bone. Acta Morph. Hung. (Budapest) 10:102.

Harsányi L, and Nemeskéri J (1964) Über Geschlechtsdiagnose an Skelettfunde. Acta Medidinae Legalis et Socialis (Liege) 17:51-56.

Hillebrand L (1908a) Ujabb adatok az ember fogainak alaktanához [Further data on the morphology of the teeth of man]. Budapest: Stephaneum.

Hillebrand J (1908b) Ujabb adatok az ember fogainak alaktanához [Further data on the morphology of the teeth of man]. Stomat. Közl. 7:29-112,113-115. 


\section{DENTAL ANTHROPOLOGY IN HUNGARY}

Hillebrand J (1909) Beiträge zur Morphologie der menschlichen Zähne. Budapest: Petöfi Ny.

Huszár Gy (1945) Az árpádkori magyarság fogazata [Teeth of Hungarians from Árpád Age]. Máthé Dénes emlékkönyv, Budapest, pp. 77-81.

Huszár Gy (1951) A torus palatinus morfológiája és fogászati jelentösége [Morphology of torus palatinus and its dental importance]. Fogorv. Szle. 44:65-71,108-116.

Huszár Gy (1961) Ergebnisse der paleostomatologischen Untersuchungen im Lichte der Ernährungskunde. 7 Int, Vitalstoffkonvent. Aachen, Rigbuch. 67.

Huszár Gy (1963) Die spätmittelalterliche Bevölkerung von Fonyód. Paleostomatolgie. Anthrop. Hung. 6:158.

Huszár Gy (1965) Die Konsistenz der Ernährung und Kariesfrequenz. Vitalsoffe-Zivilizationskrankheiten 10:207.

Huszár Gy (1967) Zahnkrankheiten im Lichte medizinischen Geographie. Vitalsoffe-Zivilizationskrankheiten 12:10-11.

Huszar Gy (1966) Midizingeographische Aspekte der Zahnkaries. Gorgr. Med. Hung. O:25-30.

Huszár Gy (1968) Karies und Zahnabnützung. Vitalsoffe-Zivilizationskrankheiten 12:16.

Huszár Gy (1972) Milchgebissabnützung einst und jetzt. Protectio Vitae 17:213.

Huszár Gy (1974a) A tejfogak kopása [Abrasion of milk teeth]. Fogorv. Szle. 67:1-5.

Huszár Gy (1974b) Abrasio dentium fiatal korban. Anthrop. Közl. 18:97-103.

Huszár Gy (1976) A fogkopás vizsgálatainak ujabb mószerei és ezek alapján végzett összehasonlitó értékelések eredményei [Further methods of testing teeth abrasion and the results of comparative evaluation using these methods]. Akadémiai Doktori Tézisei, Budapest.

Huszár Gy, and Schranz D (1952) A fogszuvasodás elterjdése a Dunántúlon az ujabb kökortól az ujkorig [Incidence of dental caries in the area of Transdanubia from the Neolithic Age to the modern time]. Fogorv. Szle. 45:171-182,200-206,233-243,272-279.

Huszár Gy, and Schranz D (1954) A foglekopás statisztikal értékelése csontmaradványookon [Statistical evaluation of dental abrasion on osteological remains]. X. Arkövy vándorgyülés. Debrecen: Elöadások Összefoglalója.

Iszlay J (1881a) Fogazatbeli különbségek az emberi nem fö jellegeinél [Morphological differences of human teeth]. Orv. Hetilap. 25:18-19,37-40,76,-78,97-100,139-143.

Iszlay J (1881b) Fogazatbeli különbségek az emberi nem fö tipusainál [Differences of teeth among the main types of human races]. Ttud. Közl. 13:159-165.

Jójárt A (1988) Állcsontok méretváltozásai torzitott koponyákon [Metrical differences of mandibles on deformed skulls]. Szeged: Szakdolgozat, Szote.

Kemenes I (1970) Ërdekes anthropo-odontologiciai muzeumi lelet [A curious anthropo-odontological finding]. Fogorv. Szle. 63:50-51.

Kiszely I (1966) A szentendrei longobárd temetö embertani vizsgálata [Anthropological investigation in the longobard cemetery in Szsntendre]. Anthrop. Közl. 10:57-90.

Kocsis GS (1988) Hódmezövásárhely Gorzsa-Csukor major ujkökori temetö embertani anyagának fogantropologiai és patológiai leirása [Dental anthropological and pathological description of the anthropological finds which originated from the modern time of Gorzsa-Csukor farm cemetery, Hódmezövásárhely]. Móra Ferenc Muzeum Ëvk. 1987, pp. 69-79.

Kocsis GS (1989) Untersuchungen an aus Asugarbungen Stammenden Zähnen und Kiefern in Ungarn (Literaturübersicht). Acta Biol. Szeged 35:175-190.

Kocsis GS, and Marcsik A (1979) Avarkori koronyán észlelet rendelleneségegyüttes [Disorder complex on the skull from the Avar period]. Anthrop. Közl. 23:83-86.

Kocsis GS, and Marcsik A (1980) Extradental, paracoronal formations of tooth enamel from the 7th-8th centuries. Proceedings of the Paleopathology Association, $3^{\text {rd }}$ European Meeting, Caen, pp. 183-188.

Kocsis GS, and Marcsik A (1981) Zománckérzödények a VII-VII. századból származó koponyák fogain [Enamel formation on the teeth of skulls from the VII-VIII century]. Fogorv. Szle. 74:89-93.

Kocsis GS, and Marcsik A (1982) Stellungsanomalien der Zähne an Schädeln aus dem VIII Jahrhundert. Humanbiol. Budapestiensis 10:105-110.

Kocsis GS, and Marcsik A (1983a) Forms and aetiology of the enamel formations in the cervical zone of teeth (Literary summary). Paleobios. 1:53-58.

Kocsis GS, and Marcsik A (1983b) Appearance and incidence of coronal dens invaginatus on the basis of studies on recent and paleoanthopological samples. Acta Biol. Szeged 29:189-197.

Kocsis GS, and Marcsik A (1987) Palatinal Groove Formation on the Upper Incisors. The Eighth European Anatomy Congress, Antwerpen, Sept. 6-12, 1987. Abstracts. Acta Anat. Add., 130.

Kocsis GS, and Marcsik A (1989) Accessory root formation on a lower medial incisor. Oral Surg. Oral Med. Oral Path. 68:664-645.

Kocsis GS, and Marcsik A (1991) Two developmental anomalies of the teeth and resulting secondary pathosis. In DJ Ortner and AC Aufderheide (eds.): Human Paleopathology. Current Synthesis and Future Options. Washington: Smithsonian Institution Press, pp. 273-280.

Kocsis GS, and Mari A (1988) A palatinális-gingivális barázda [Palatinal and gingival line]. Fogorv. Szle. 81:193-197.

Kocsis GS, and Trogmyer H (1986) A fogak fejlödési rendellensségei Vésztö-Mágori halom ujkökori és rézkori temetö embertani anyagában [Developmental disorders of teeth in anthropological finds obtained from the Neolithic and Copper Age cemetery of Vésztö-Mágor hill]. Móra Ferenc Muzeum Ëvk. 1984/85:65-76.

Kocsis GS, Marcsik A, and Mann RW (1992) Idiopathic bone cavity on the posterior buccal surface of the mandible. Oral Surg. Oral Med. Oral Path. 73:127-130.

Kollar L (1948) A zengövárkonyi csiszolt kökorszakbeli állcsontleletek [Mandible in finds in Zengövárkony from the Neolithic period]. Fogorv. Szle. 41: 289-276. 
Könegyi M, and Marcsik A (1976) Anatómia variáciok fejlödési rendellenességek és szelektált patológiás leletek egy avarkori sorozatbátol [Anatomical variations, developmental disorders, and selected pathological finds from the Avar period]. Comm. de Hist. Artis. Med. 77:9-25.

Kósa F (1978) Identifikation des Feten durch skelettuntersuchungen. In H Hunger and D Leopold (eds.): Identifikation. Leipzig: Johann Ambrosius Barth, pp. 215-241.

Kósa F (1984) Rasterelektronmikroskpische Untersuchungen an menschlischen Zähnen zur Altersbestimmung. Kriminalistik u. forens. Wissenschaften 55.56:97-102.

Kósa F (1989) Age estimation from the fetal skeleton. In Y. Iscan (ed.): Age Markers in the Human Skeleton. Springfield: Charles C. Thomas, pp. 21-54.

Kósa F (1990a) Involution of the alveolar process of the toothless mandible in the respect of determining age. Abstracts. International Symposium on Paleopathology. August 31-Sept. 2, Warsaw. Poland.

Kósa F (1990b) The use of scanning electromicroscopy for estimating age at death in the adult skeleton. Am. J. Phys. Anthropol. 81:252.

Kósa F, and Antal A (1988) Metrical and structural study of the dental canal to determine the individual age. Acta Medicinae Legalis et Socialis XIVth Congress of the International Academy for Legal Medicine. Liege, 11-17 Sept. Abstracts, Vol. II pp. 160,161 .

Kósa F, Antal A, and Farkas I (1990) Electron probe microanalysis of human teeth for the determination of individual age. Med. Sci. Law 30:109-114.

Kósa F, Farkas I, and Wittman Gy (1989) A csontok elektronmikroszondás vizsgálata az indivudális életkor megállapitására [Electron microprobe analysis of the human bones for determination of individual age]. Morph. Igazságü. Orv. Szle. 29:227-232.

Kósa F, Ferenczi F, and Baláspiri L (1985) Untersuchungen des aminosaure Alters mittels automatischer Aminosaureanalyse. Festschrift für Horst Leithoff zum 65. Kriminalistik, Verlag Heidelberg, pp. 375-387.

Kósa F, Szendrényi J, and Töth V (1983) A fogak transzparenciájának vizsgálata az életkor megállapitására [Dental transparency and its role in the determination of age]. Morph. Igazságü. Orv. Szle. 28:286-291.

Lang P (1955) A canalis nasopalatinus seu incisivusról illetve annak röntgenképéröl [On the canalis nasopalatinus seu incisivus, i.e. about its radiogram] Fogorv. Szle. 48:68-72.

Lengyel IA (1975) Paleoserology. Blood typing with the Fluorescent Antibody Method. Budapest: Akadémiai Kiadó.

Lenhossék J (1875) The Science of the Human Skull. Cranioscopy Budapest.

Lonhossék J (1915) Anthropology and the Work to Be Done in the Field. Budapest: Franklin Társulat.

Lenhossék J (1917a) A fogszu pusztitása egykor és most [Destruction of dental caries then and now]. Ttud. Közl. 49:333-360.

Lenhossék J (1917b) A fogodvasodás (caries) gyakorságáról [On the prevalence of caries]. Orv. Hetilap. 61:176.

Lenhossék J (1918) A fogszu egykor és most [The caries then and now]. Mat. Ttud. Ért. 36:1-2 füz. 1-35.

Lenhossék J (1918) Die Zahnkaries einst und jetzt. Archiv. f. Anthrop. 17:44-66.

Lenhossék J (1920) Das innere Relief des Unterkieferastes. Archiv. Anthrop. 18:48-49.

Lonhossék J (1921) Man's Place in Nature. Budapest: Franklin Társulat.

Lenhossék J (1922) Makroskpoische Anatomie. In Handbuch der Zähnheilk. Erin: J. Scheff, Urban, and Schwarzenberg, Vol. 1-2, pp. 1-324.

Lipták P (1967) The Paleoanthropology of Hungarian Ethnogenesis. D.Sc. Thesis Manuscript. Budapest, Szeged.

Lipták P (1969) Anthropology and Human Evolution. Budapest: Tankönyvkiadó.

Lipták P (1976) Anthropology of the Finno-Ungarian peoples. In P Hajdu (ed.): Ancient Cultures of the Uralian Peoples. Budapest: Corvina, pp. 133-142.

Lipták P (1980) Anthropology and Human Evolution, 2nd Edition. Budapest: Tankönyvkiadó.

Lipták P (1983) Avars and Ancient Hungarians. Budapest: Akademaia Kiadó.

Malán M (1944) Transylvanian Hungarians and Roumanians in the mirror of anthropology. Történettudományi Intézet Évkönyve (Budapest), pp. 599-667.

Malán M (1955) Zahnkeim aus der zweiten Aurignacien Schicht der Höhle von Istállóskö. Acta Arch. Hung. 5:145-148.

Malán M (1961) Ergebnisse der ethnisch-anthropologischen Forschungen des Ungartums. Anthrop. Közl. (Budapest) 5:107-116.

Marcsik A (1976) The anthropological description of the skeleton from the period of the Hungarian conquest found at Izsák-Balázspuszta. Cumania, IV. Archaeológia, Bács-Kiskun Megyei Muz. Közl. Kecskemét, pp. 185-190.

Marcsik A (1983) A Duna-Tisza köze avarkorának paleopathológiája [Paleopathology of the Avar period in the area between the Danube and the Tisza]. Szeged: Candidate's Dissertation.

Marcsik A (1989) On the association of Harris lines, enamel hypoplasia and porotic hyperostosis. Paleobios. 5:2-3,55-59.

Marcsik A, and Baglyas B (1987) The frequency of enamel hypoplasia from the eighth century in Hungary. J. Paleopath. $1: 25-32$.

Marcsik A, Kósa F, and Kurucz E (1984) Scanning electron microscopic investigations into paleopathological findings (porotic hyperostosis). $V^{\text {th }}$ European Meeting Sienna Paleopathology Association. Sienna: Publications of Sienna University, pp. 219-234.

Marcsik A, and Kocsis GS (1984) Kettös gyökerü alsó canius gyakorságáról és filogenetikai elözményeiröl [Frequency of the double-rooted lower canine and its phylogenetic background]. Anthr. Közl. 28:97-106.

Marcsik A, and Kocsis GS (1985) A Stafne-féle idiopathiás állcsontüreg gyakorisága paleoanthropológiai leleteken [The prevalence of the Stafne idiopathic hole of the mandible on paleoanthropological finds]. Fogorv 78:207-210.

Marcsik A, and Kocsis GS (1986) The connections of the anomalies of teeth in paleoanthropological material. Proceedings. VI European Meeting of the Paleopathology Association, Madrid, pp. 237-240. 


\section{DENTAL ANTHROPOLOGY IN HUNGARY}

Marcsik A, and Kocsis GS (1992) Occurrence of enamel hypoplasia in prehistoric and historic skeletal samples (Hungary). In AH Goodman and LL Capasso (eds.): Recent Contributions to the Study of Enamel Developmental Defects. Journal of Paleopathology. Monographic Publications 2, pp. 219-229.

Marcsik A, Kósa F, and Kocsis GS (1992) The possibility of age determination on the basis of dental transparency in historical anthropology. In P Smith and E Tchernov (eds.): Structure, Function and Evolution of Teeth. London: Freund Publishing House, pp. 527-538.

Mathé D, and Molnár L (1940) Artikuláció a természetes fogazatban, különös tekintettel a lerágott fogazatra [Articulation in the natural teeth with a special regard to weird teeth]. Fogorv. Szle. 33:1-10,37-47.

Méhely L (1925) A fogazat származástani jelentösége [Genealogical importance of teeth]. Fogorv. Szle. 18:193-218.

Molnár L (1939) Abkauungserscheinungen an natürlichen Zähnen un ihre Nutzbarmaching für die Formgestaltung künstlicher Zähne. Zschr. Stomatol. 37:124-133,191-210,255-268.

Molnár L, and Huszár Gy (1953) A nemi különbség jelentösége a stomatológiában [Consequence of the difference in sex in stomatology]. Fogorv. Szle. 46:133-141.

Nemeskéri J (1943) Anthropology and Hungarian prehistory. In L Ligeti (ed.) The Prehistory of Hungarians. Budapest, pp. 223-239.

Nemeskéri J (1947) Hungarians from the Conquest Age, Hungarians from the Arpád Age. Anthrop. Hung. (Budapest) $1: 64-80$.

Nemeskéri J, and Harsányi L (1968) A hamvasztott csontvázleletek vizsgálatának kérdései [Questions of the investigation of cremated skeletal finds]. Anthrop. Közl. 12:99-116.

Nemeskéri J, and Dezsó Gy (1969) (eds.): Evolutionary Trends in Fossil and Recent Hominids. Symp. Biol. Hung. 9. Budapest: Akadémiai Kiadó.

Nemeskéri J, Harsányi L, and Acsadi G (1960) Methoden zur Diagnose del Lebensalters von Skelettfunden. Anthrop. Anz. (Stuttgart). 24:70-95.

Nitsche H, and Válye E (1958) Az állkkapocsfejecs kongifurációja és röntgenvetülete koponyavizsgálatok alapján [Configuration and roentgen projection of the capitulum of the mandible on the basis of investigation of the skull]. Anthrop. Közl. 2:37-41.

Pap I (1986) Oral pathology and social stratification in the Hungarian Middle Ages. Annls. Hist. Nat. Mus. Nat. Hung. 78:339-345.

Pónyi S, and Nyilasi J (1971) Ujrendszerü kephalostat és az arcprofil planimaetriás mérése [A cephlaostat with a new system, and planimetry of the facial profile]. Anthrop. Közl. 15:49-52.

Pónyi S, and Szabó Gy (1989) Reference values on historical anthropological replacements (Methodological considerations). Acta Biol. Szeged 35:221-229.

Prágai G (1982) A fogatlan mandibula involuciója a moláris fogak táján és a környezö lágyrészek változása [Involution of a toothless mandible in the region of the molar teeth and the change of the surrounding soft tissues]. Kandidátusi értekezés tézisei. Szeged.

Prágai G, and Fazekas A (1982) Az állkapocsgerinc magasságának̉ vizsgálata a moláris fogak tájékán, anthropologiai leletekböl származó mandibulákon [Investigations of the height of the spine of the mandible in the region of molar teeth]. Fogorv. Szle. 75:231-235.

Prágai G, and Fazekas A (1983) Die Kieferkammhöhe untersucht an anthropologischem und klinischem material. ZWR 92:61.

Regöly-Mérei Gy, and Nemeskéri J (1958a) Paleopathologische Untersuchungen an ägyptischen Mumien aus der Römerzeit. Virchows Archiv. 331:569.

Regöly-Mérei Gy, and Nemeskéri J (1958b) Paleopathologiai vizsgálatok ó-egyiptomi mumiákon [Paleopathological investigation of mummies from ancient Egyptian finds]. Anthrop Közl. 1:81.

Rudas G (1899a) Tunalmány a fogak és csontok korhadásáról [Study of the decomposition of teeth and bones]. Magyar Fogászati Szle. 3:179-186.229-234,262-266.

Rudas G (1899b) A csont - és fogszövetben halál után létrejött némi elváltozásról [Some changes in bone and tooth tissue after death]. Magyar Fogászati Szle. 3:341-345.

Salamon H (1923) Petöfi kopanyája és rendellenes fogazatának meghatározása. Fogorv. Szle. 16:3-56.

Salamon H (1938) Liszt Ferenc fogai [The teeth of Ferenc Liszt]. Fogorv. Szle. 31:97-114.

Salamon H (1940a) Alvinczy tábornagy vendégfogai. [Guest teeth of Field Marshal Alvinczy]. Fogorvosok Lapja 2:409-414.

Salamon H (1940b) II. Rákóczi Ferenc felesésgének halála [Death of the wife of Ferenc Rákóczi II]. Fogorv. Szle. 33:28-297.

Salamon H (1941) II Lajos magyar király tetemének felismerése [Identification of the dead body of the Hungarian King Lajos II]. Fogorvosok Lapja 3:22-28.

Salamon H (1942) Mátyás király koponyájának azonositási lehetösége [A possible method to identify the skull of King Mátyás]. Fogorv. Szle. 35:261-274.

Scheiber S (1873) "Pro memoria" in matter of establishment of anthropological museum. A Hon. Pest.

Schranz D (1953) A személyazonosság megállapitása a fogászati lelet alapján [Establishment of identity by means of dental findings]. Fogorv. Szle. 46:225-231

Schranz D (1956) Forensic Stomatology. Budapest: Budapesti Orvostudományi Egyetem Fogorvosi Kar.

Schranz G (1962) Zahnbetterkrankungen der längstvergangenen Zeit. Zschr. Morph. Anthrop. 52:347-354.

Schranz D (1964) Morphologische Unterschiede männlicher und weiblicher Zähne. Acta Morph. Hung. (Budapest) 12:401-406.

Schranz D (1967) Abnützung des Gebisses des fossilen und rezenten Menschen und die Bedeuting des Kauens in der stomatologischen Propylaxe. Acta Med. Hung. 24:89-92. 


\section{DENTAL ANTHROPOLOGY IN HUNGARY}

Schranz D (1988) III. Béla csontmaradványainak vizsgálata fogászati szempontból [Investigation of the remains of the bones of Béla III from a dental point of view.]. Fogorv, Szle. 81:103-109.

Schranz D, and Huszár Gy (1954) Az öskori ember fogbetegségei [Dental disease in prehistoric man]. Fogorv. Szle. 47:218-226.

Schranz D, and Huszár Gy (1955) Die Paleopathologie des prehistorischen Menschen in Ungarn. Österr. Zschr. Stomatol. $52: 247-258$.

Schranz D, and Huszár Gy (1958) Die Kinderzahnkaries der Vergangenheit in Ungarn. Österr, Zschr. Stomatol. 55:587-594.

Schranz D, and Huszár Gy (1962) Caries findings on prehistoric human dentitions from Hungary. Zschr. Morph. Anthrop. 52:141-154.

Simon B, and KömIves O (1937) Az állkapocs felhágó ágának méretei és helyzeti variációi [Dimension and positional variation of the ascendant branch of the mandible]. Fogorv. Szle. 46:49-76.

Somogyi B (1953) Az állkapocs féloldali fejlödési rendellenességei, változatai és részaránytalanságai sebészanatómiai szempontból [Unilateral developmental disorders, variations and asymmetries of the mandible from a surgical-anatomical point of view]. Fogorv. Szle. 46:193-199.

Szabó J (1934) Skeletal remains of early man in a cave named "Subalyuk". J. Dent. Res. 14:204.

Szabó J (1935) L Homme moustérien de la grotte Mussolini (Hongrie) Édute de la mandible. Bull. Mém. Soc. Anthrop. Paris 6:23-30.

Szabó J, and Doby D (1972) Az angulus mandibulae szögének idöskori változása [Changes in the angle of the mandible in old age]. Fogorv. Szle. 65:270-274.

Szarvas E (1981) Foganimáliák és fogmegbetegedések Szeged környéki avarkori [Anomalies and disease of the teeth in skulls from the Avar Age in the environs of Szeged]. Szeged: Szakdolgozat, JATE.

Szentpétery A, Kocsis GS, and Marcsik A (1990) The problem of the bifid mandibular condyle. J. Oral Maxillofac. Surg. 48:1254-1257.

Szikáry I, and Huszár Gy (1933) Beiträge zur Anthropologie Ungarns im XI Jahrhundert. MAG 63:229-232.

Szokolóczy-Sillaba B (1937) Merések az állkapocs felhágo szárán különös tekintettel a vezetéses érzéstelenitésre [Measurements of the ascending ramus of the mandible with special regard to conduction of anesthesia]. Fogorv. Szle. 30:439-449.

Szokolóczy-Sillaba B (1939) Measurements of the ascending ramus of the mandible. J. Dent. Res. 18:561.

Szokolóczy-Sillaba B (1953) Mérése adatok a lingual szintjének meghatározásához [Survey data on the estimation of the lingula level]. Fogorv. Szle. 46:177-180.

Tamás F (1986) A canalis mandibulae helyzetének röngtengvizságlata száraz csontanyagon [Radiographic examination of the position of the mandible in dried skeletal materials]. Fogorv. Szle. 79:304-308.

Thoma A (1963) The dentition of the Subalyuk Neanderthal child. Z. Morph. Anthrop. (Stuttgart) 54:127-150.

Thoma A (1966) Az elöember fogmaradványai a vértesszöllösi östelepröl [Remains of teeth of the prehistoric man in the ancient cemetery in Vértesszölös]. MTA Biol. Orv. Tud. Oszt. Közl. 9:263-282.

Thoma A (1967) Teeth from the Lower Paleolithic of Hungary. Zschr. Morph. Anthrop. 58:152-180.

Tóth K (1966a) Ujabb adatok a VII-XIII. században Magyarország területén élt népek fogaszati állapotának megitéléséhez [Further data for evaluation of the peoples living in the area of Hungary in the VII-XIII centuries]. Fogorv. Szle. 59:102-115.

Tóth K (1966b) A processus alveolaris állapota az avar - és Arpád-kori koponyák vizsgálata alapján [State of the processus alveolaris in the study of the skull from the Avar Age]. Fogorv. Szle. 59:1-11.

Tóth K (1966c) Alveolarfortsatzbefunde an Schädeln der Völkerwanderungsperiode und des Arpaden-Reiches. Dtsch. Zahn-, Mund-, Kieferheilk. 46:100-103.

Tóth K (1967a) Zivilization und Zahnkaries. Vitalstoffe-Zivilizationskrankheiten 12:142-145.

Tóth K (1967b) Incidence of dental caries in Hungary from the 7th to the 13th centuries. J. Dent. Res. $46: 751$.

Tóth K (1967c) A felsö és alsó fogak szuvasodási hajlama a multban [Diathesis to caries of the upper and lower canines in the earlier period of age]. Fogorv. Szle. 60:161-169.

Tóth K (1967d) A fogsuvasodás epidemiológiája Magyarországon [Epidemiology of caries in Hungary]. Akadémiai doktori értekezés tézise, Budapest.

Tóth K (1968) Megegyzések Lenhossék M. "A fogszú egykor és most" c. közleményéhez [Comment on Lenhossék's report entitled "Caries then and now"]. Fogorv. Szle. 61:81-85.

Tóth K (1970a) The Epidemiology of Dental Caries in Hungary. Budapest: Akadémiai Kiadó.

Tóth K (1970b) A fogszuvasodás megjelenése elterjedése és a jelenlegi helyzet Magyaroszágon [Appearance, prevalence of caries and the present situation in Hungary]. Orv. Hetilap 111:2523-2530.

Tóth K, and Sonkodi I (1972) Tápé lelëhelyöl származó bronzkori fogazati állapota [State of teeth in the skull in the finding place in Tápé originated from the Bronze Age] Fogorv. Szle. 65:257-264.

Tóth TA (1980/81) Anthropological results concerning the ethnogenesis of Hungarians. Anthrop. Hung. (Budapest) 17:5-22.

Török A (1882) Injuries on bones in prehistoric man. Anthropologiai Füzetek (Budapest) 1:188-198.

Török A (1890) Grundzüge Einer Systematischen Kraniometrie. Stuttgart: F. Enke Verlag.

Török A (1898) Über Variationen und Correlationen der Neigungs-Verhältenisse am Unterkiefer. Eine Studie zur Frage des kraniologischen Typus. Zschr. Ethn. 30:125-182.

Török A (1899) Über die Stellung der Längenaxen der Gelenkköpfe beim menschlichen Unterkiefer. Zschr. Morph. Anthrop. 1:379-450.

Vajdovich I, and Dinnyés I (1989) A canalis mandibulae lefutásának vizsgálata fosszilis és kórbonctani leletekböl származó mandibulákon [The course of the mandibular canal in fossil and postmortem mandibles]. Morphologiai és Ig. Orv. Szle. 29:39-47. 